\title{
Terapi Penyakit Maksiat Menurut Ibnu Al-Qayyim Al-Jauziyyah
}

\author{
Sakha Meindra Putra ${ }^{1 *}$, Isep Zaenal Arifin ${ }^{2}$, Siti Chodijah ${ }^{3}$ \\ 123Jurusan Bimbingan dan Konseling Islam, UIN Sunan Gunung Djati, Bandung \\ *Email:Sakhameindra@gmail.com
}

\begin{abstract}
ABSTRAK
Penelitian ini bertujuan untuk mengetahui biografi Ibnu Al-Qayyim AlJauziyyah mengenai konsep penyakit maksiat dan terapi yang diberikan kepada pengidap penyakit maksiat tersebut. Metode yang digunakan dalam penelitian ini merupakan Analisis Isi (Content Analisis). Konsep penyakit menurut Ibnu AlQayyim Al-Jauziyyah mengenai maksiat dibagi menjadi tiga pengertian yang menjelaskan bahwa maksiat merupakan racun, perbuatan yang keluar dari norma dan kedurhakaan yang membawa pada kedurhakaan yang lainnya. Proses terapi yang diberikan ialah dengan Irsyad (konseling), Tabyîn (Penjelasan), Tanbîh wa Tahdîd (Peringatan dan Ancaman), Amr bi Taqwa wa Nabyu a'n Ma'shiyah (Menyeru pada Ketakwaan dan Mencegah kemaksiatan), al-Birru wa at-Tha'atu (Perbuatan baik dan Ketaatan), Mauizhah tentang al-Qur'an, Iman, Kematian, Neraka dan perkara yang menghapus kebaikan atau pahala, Do'a, Dzikir dan Ta'lîl.
\end{abstract}

Kata Kunci : Terapi; Psikoterapi; Penyakit; Jiwa; Maksiat.

\begin{abstract}
This study aims to find out the biography of Ibn Al-Qayyim Al-jauriyyah about the concept of immorality. The concept of illness according to Ibn Al-Qayyim Al-Jauriyyah regarding immorality is divided into three definitions which explain that immorality is a poison, is an act that goes out of the norm and vice is a violation that leads to other acts of disobedience. The therapeutic process is given by Irsyad (counseling), Tabyin (Explanation), Tanbîh wa Tabdid (Warnings and Threats), Amr bi Taqwa wa Nabyu a'n Ma'shiyab (Call upon Prayers and Prevent disobedience), al-Birru wa at-Tha'atu (Good Deeds and Obedience), Manizhah of the Qur'an, Faith, Death, Hell and the things that wipe out good or reward, Dhamma, Drikir and Ta'lîl.
\end{abstract}

Keywords : Therapy; Psychotherapy; Disease; Soul; Immoral. 


\section{PENDAHULUAN}

Pada awal mula penciptaan manusia yaitu zaman Nabi Adam dan Siti Hawa, satu hal yang membuat keduanya dikeluarkan dari surga-Nya dikarenakan kedurhakaan terhadap perintah Allah SWT untuk tidak mendekati pohon Khuldi. Akan tetapi akan takdir-Nya Nabi adam beserta istrinya tidak hanya mendekati bahkan memakan buah tersebut sehingga Allah SWT menurunkan mereka berdua dari alam penuh kelezatan, kenikmatan, keindahan dan kegembiraan ke alam dunia yang penuh dengan penderitaan, kesedihan, dan musibah hal itu dikarenakan kemaksiatan. Begitupula kisah iblis yang bermaksiat karena sombong dan enggan untuk sujud kepada Nabi Adam sehingga membuatnya terusir dari Rahmat Allah SWT. Kedekatan Iblis dengan Allah SW'T berubah menjadi jauh; Rahmat menjadi Laknat; Keindahan menjadi Kejelekan; Surga menjadi Neraka yang berkobar; iman menjadi kekufuran; pertolongan menjadi permusuhan; penentangan, gema tasbih, tahlil dan penyucian menjadi gema kekufuran, kesyirikan, kedustaan, dan kebejatan; serta pakaian keimanan menjadi pakaian kekufuran, kefasikan, dan kedurhakaan. Maka terhinalah Iblis dihadapan Allah SWT, serendah-rendahnya, dan jatuhlah kedudukannya dalam pandangan-Nya (Adni, 2016: 100)

Begitulah perbuatan Maksiat yang merupakan perbuatan jahat atau dosa yang tidak mentaati norma-norma agama. Dalam perspektif lain maksiat merupakan perbuatan yang menyimpang dan melanggar dari norma-norma agama dan hukum yang berlaku. Maksiat mencakup segala perbuatan yang merusak moral dan sendi-sendi kehidupan bermasyarakat yang islami, seperti prostitusi, pornografi, pemerkosaan, zina, minum-minuman keras, berjudi, pembunuhan dan lain-lain. Padahal hal-hal seperti ini pada zaman sekarang merupakan perbuatan keluar dari norma yang bisa kita temui sehari-hari dan terkadang terjadi secara terang-terangan. Seperti penggunaan narkotika, miras, seks bebas dan lain sebagainya.

Bahkan Ibnul Qayyim al-Jauziah mengatakan bahwa dosa dan kemaksiatan sangat membahayakan dan merugikan hati, hal ini bagaikan angin panas terhadap badan (Qayyim, 2005: 65). Artinya, setiap perbuatan yang mengarah pada dosa dan kemaksiatan maka akan mengakibatkan jiwa dan fisik seseorang menjadi lemah dan sakit, atau dalam istilah psikologi klinis hal ini disebut dengan psikosomatis.

Atas dasar itulah peranan psikoterapi dibutuhkan guna untuk meminimalisir dan mengobati berbagai masalah dalam kehidupan manusia berupa gangguan jiwa. Belakangan ini, banyak upaya dikerahkan dalam bidang psikoterapi bagi individu-individu yang mengalami gangguan kepribadian dan gangguan jiwa (Najati, 2005: 422)

Snyderman beranggapan bahwa terapi medis saja tanpa disertai dengan 
Terapi Penyakit Maksiat Menurut Ibnu Al-Qayyim Al-Jauziyyah berdoa dan berdzikir tidaklah lengkap. Berdoa dan berdzikir saja tanpa disertai dengan terapi medis, tidaklah efektif (Hawari, 2002: iii)

Zwisr Wollberg MD, dalam bukunya yang berjudul "The Technique of Psikotherapy" mengatakan:

"Psikoterapi adalah perawatan dengan menggunakan alat-alat psikologis terhadap permasalahan yang berasal dari kehidupan emosional dimana seorang ahli menciptakan hubungan profesional dengan bertujuan: 1) menghilangkan, mengubah, atau menemukan gejala yang ada, 2) memperantai (perbaikan) pola tingkah laku yang rusak. 3) meningkatkan pola pertumbuhan serta perkembangan kepribadian yang positif, dan pada hakikatnya Allah lah yang Maha Penyembuh, Maha Obat dan Maha Penyehat" (Sholikhin, 2003: 35)

Bukti-bukti diatas dapat kita pahami bahwa Agama Islam merupakan psikoterapi yang jelas. Agama mempunyai konsep tentang manusia yang jelas, yaitu sebagai makhluk jasmani dan rohani, dengan segala aspeknya, mempunyai tujuan yang mabni, yaitu pengabdian terhadap Tuhan Yang Maha Esa Realitanya bisa melalui ibadah, latihan mengendalikan diri, berkhalwat, puasa, sholat, zikir, wirid, dan latihan mental lainya (Darajat, 1976: 981)

Disinilah peranan psikoterapi Islam dibutuhkan, yaitu dengan menciptakan hubungan profesional dengan bertujuan: 1) menghilangkan, mengubah, atau menemukan gejala yang ada, 2) memperantai (perbaikan) pola tingkah laku yang rusak. 3) meningkatkan pola pertumbuhan serta perkembangan kepribadian yang positif, dan pada hakikatnya Allah lah yang Maha Penyembuh, Maha Obat dan Maha Penyehat.

Sementara itu, Syaikh Ibnul Qayyim Al-Jauziah merupakan seorang ulama salaf dalam bidang kedokteran, psikiater dan pensucian jiwa. Seorang dokter dan psikiater pada umunya menggunakan metode kedokteran dan empiris. Namun, apa yang beliau lakukan lebih banyak memberikan fatwa-fatwa atas apa yang ditanyakan kepada beliau dengan jawaban sesuai Al-Quran dan As-Sunnah. Hal ini karena menurut beliau agama merupakan kebutuhan dasar bagi manusia sehingga terapi belum dianggap lengkap jika aspek religi belum dimasukkan.

Uraian psikoterapi Islam menurut Ibnul Qayyim Al-Jauziah terdapat dalam kitab beliau yang berjudul “al-Dã'u wa al-Dawã'u” yang artinya macammacam penyakit hati yang membahayakan dan resep pengobatannya, buku tersebut diterbitkan Dar Ibnul Jauzi di kairo tahun 2012, dan terdiri dari 115 judul yang berisikan tentang fatwa-fatwa beliau dalam memberikan bimbingan dan konseling kepada klien. Hal hal menganai terapi beliau terdapat dalam beberapa bab inti yang membahas tentang Dzunub "Kemaksiatan"

Dari uraian di atas, peneliti akan menjelaskan bagian berkenaan dengan terapi Ibnul Qayyim Al-Jauziah dalam Kitab “al-Dã'u wa al-Dawã'u” terhadap penyakit maksiat yaitu yang berada dalam Bab Dampak Negatif Maksiat Dan 
S. M. Putra., I. Z. Arifin., S. Chodijah.

Dosa pada halaman 48, Bab Hubungan antara Dosa Dan Hukuman pada halaman 123, Bab Dosa Dosa Besar pada halaman 152, Bab Pintu-pintu Dosa dan Maksiat pada halaman 167 dan Bab Menjaga Kesucian Diri. Dengan dibantu dengan beberapa karya tulis sekunder lainya untuk menjelaskan isi dalam tulisan Ibnu Al-Qayyim Al-Jauziyah tersebut. Dari latar belakang masalah diatas, dirumuskan pertanyaan penelitian yaitu, (1) bagaimana biografi Ibnu AlQayyim Al-Jauziyyah? (2) bagaimana konsep penyakit maksiat menurut Ibnu Al-Qayyim Al-Jauziyyah? (3) bagaimana terapi yang diberikan kepada pengidap penyakit maksiat?

Metode yang digunakan dalam penelitian ini adalah Analisis Isi (Content Analisis) sehingga diharapkan dapat memberikan kesimpulan yang jelas dan benar. Adapun tekhnik pengumpulan data menggunakan cara studi kepustakaan (Library Research).

\section{LANDASAN TEORITIS}

Teori yang digunakan dalam penelitian ini merupakan teori mengenai Psikoterapi dan teori mengenai penyakit maksiat. Psikoterapi secara bahasa ialah berasal dari kata "psyche" dan "theraphy." Psyche mempunyai beberapa arti, antara lain: Pertama, jiwa dan hati (Echol dan Hasan, 2005: 454). Kedua, dalam bahasa Arab psyche dapat dipadankan dengan "nafs" dengan bentuk jamaknya "anfus" atau "nufus." Ia memiliki beberapa arti, di antaranya, jiwa, ruh, darah, jasad orang, diri dan sendiri (Munawir, 1545).

Dari beberapa arti secara etimologis tersebut, dapat difahami, bahwa psyche atau nafs adalah bagian dari diri manusia dari aspek yang lebih bersifat ruhaniyah dan paling tidak lebih banyak menyinggung sisi yang dalam dari eksistensi manusia, ketimbang fisik atau jasmaniyahnya.

Adapun kata "therapy" (dalam bahasa Inggris) bermakna pengobatan dan penyembuhan, sedangkan dalam bahasa Arab kata therapy sepadan dengan kata syafa, yasyfi, syifa (menyembuhkan) (Munawir, 782)

Psikoterapi adalah bentuk khusus dari interaksi antara dua orang pasien dan terapis pada mana memiliki dari interaksi. Karena mencari bantuan psikologis dan terapi menyusun interaksi dengan menggunakan dasar psikologis untuk membantu pasien meningkatkan kemampuan mengendalikan diri dalam kehidupanya dengan mengubah pikiran, perasaan, dan tindakanya (warson dan morse dalam gunarso, 1992: 155). Dan dapat juga diartikan bahwa psikoterapi (psychotherapy) ialah pengobatan penyakit dengan cara kebathinan, atau penerapan teknik khusus pada penyembuhan penyakit mental atau pada kesulitan-kesulitan penyesuaian diri setiap hari atau penyembuhan melalui keyakinan agama, dan diskusi personal dengan para guru atau teman (Chaplin, 1995: 407)

Sedangkan pengertian dari psikoterapi Islam erat kaitannya dengan 
Terapi Penyakit Maksiat Menurut Ibnu Al-Qayyim Al-Jauziyyah perawatan ruhani Islam ilmu ini membantu sisi terapi spiritualitas atau psikhis manusia dengan paradigma psiko-teo-antroposentris yaitu jenis psikoterapi yang berbasis pada agama (psikoterapi religius) yang bersandar pada keMahamutlakkan Tuhan dan upaya maksimal manusia melalui tujuh metode psikoterapi yang telah dikembangkan yaitu terapi dengan: (1) al-Qur'an), (2) Do'a, (3) dzikir, (4) shalat, (5) puasa, (6) mandi, wudhu (hidroterapi), (7) hikmah, (8) tashawuf dan tharikat. (Arifin, 2008: 33)

Psikoterapi Islam juga dapat diartikan sebagai upaya mengatasi beberapa problem kejiwaan yang didasarkan pada pandangan agama Islam. Psikoterapi Islam mempercayai bahwa keimanan dan kedekatan terhadap Allah SWT akan menjadi kekuatan yang sangat berarti bagi kebaikan problem kejiwaan seseorang. Mencegah berbagai problem kejiwaan dan menyempurnakan kualitas manusia disamping pendekatan psikospiritual (dengan keimanan dan kedekatan kepada Allah). Psikoterapi Islam juga disandarkan penggunaan alat fikir dan usaha nyata manusia untuk memperbaiki diri. Psikoterapi Islam tidak semata-mata membebaskan orang-orang dari penyakit, tetapi juga perbaikan kualitas kejiwaan dan keimanan seseorang.

Maka Jelas terapi terbaik bagi keresahan jiwa adalah keimanan kepada Allah SWT, sejalan yang ada dalam Al-Qur'an Surat Al-Isra' ayat 82:

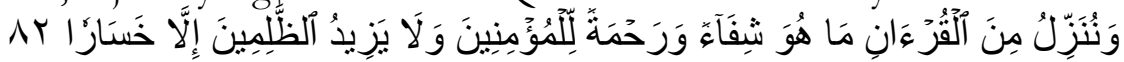

'Dan kami turunkan dari Al Qur'an sesuatu yang menjadi penawar dan rabmatbagi orang-orang yang beriman dan Al-Qur'an itu tidaklah menambah kepadaorang-orang zalim selain kerugian (Depag, 2015: 290).

Dan firman Allah SWT yang lain dalam surat Fushilat ayat 44:

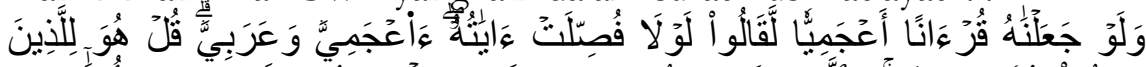

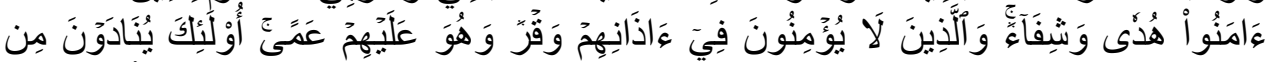

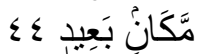

"Dan jikalau Kami jadikan Al Quran itu suatu bacaan dalam bahasa selain Arab, tentulab mereka mengatakan: "Mengapa tidak dijelaskan ayat-ayatnya?" Apakab (patut Al Quran) dalam bahasa asing sedang (rasul adalah orang) Arab? Katakanlah: "Al Quran itu adalab petunjuk dan penawar bagi orang-orang mukmin. Dan orang-orang yang tidak beriman pada telinga mereka ada sumbatan, sedang Al Quran itu suatu kegelapan bagi mereka. Mereka itu adalah (seperti) yang dipanggil dari tempat yang jaub (Depag, 2015: 481)".

Ayat-ayat yang dikutip tersebut di atas adalah merupakan petunjuk atau pelajaran, bahwa agama mempunyai sifat terapi bagi penyakit karena kedzaliman diri berupa kemaksiatan terhadap perintah dan Syariat yang ada dan penyakit tersebut memiliki ciri-ciri sebagai berikut : Pertama, hadirnya perasaan cemas dan perasaan tegang didalam diri; Kedua, merasa tidak puas (dalam artian negatif) terhadap prilaku diri sendiri; Ketiga, perhatian berlebih-lebihan terhadap problem yang dihadapi; Keempat, ketidak mampuan untuk berfungsi secara

Irsyad : Jurnal Bimbingan, Penyuluhan, Konseling, dan Psikoterapi Islam 07(4) (2019) 423-438 


\section{S. M. Putra., I. Z. Arifin., S. Chodijah.}

efektif dalam menghadapi problem (Ancok dan Anshori, 2000:91)

Sasaran atau yang menjadi fokus penyembuhan, perawatan atau pengobatan dari psikoterapi Islam adalam manusia (insan) secara utuh, yakni yang berkaitan atau menyangkut dengan gangguan pada:

Pertama, mental, yaitu yang berhubungan dengan fikiran, akal, ingatan atau proses yang berasosiasi dengan fikiran, akal ingatan (Chaplin, 1995: 296). Seperti mudah lupa, malas berfikir, tidak mampu berkonsentrasi, picik, tidak dapat mengambil suatu keputusan dengan baik dan benar, bahkan tidak memiliki kemampuan membedakan antara halal dan haram, yang bermanfaat dan mudharat serta yang hak dan yang batil (Dzakiy, 2001: 231).

Kedua, spiritual yaitu yang berhubungan dengan masalah ruh, semangat atau jiwa, religius, yang berhubungan dengan agama, keimanan, keshalehan dan menyangkut nilai-nilai transendental (Chaplin, 1995: 480). Seperti syirik, nifaq, fasiq, kufur, dan lemah keyakinan.

Ketiga, moral (akhlak) atau tingkah laku merupakan ekspresi dari kondisi mental dan spiritual. Ia muncul dan hadir secara spontan dan otomatis, dan tidak dapat dibuat-buat atau direkayasa. Perbuatan dan tingkah laku itu kadangkadang sering tidak disadari oleh subyek, bahwa perbuatan dan tingkah lakunya menyimpang dari norma-norma agama (Islam) dan akhirnya dapat membahayakan dirinya dan orang lain. Seperti liar, pemarah, sembrono, dengki, dendam, suka mengambil hak milik orang lain, berprasangka buruk, pemalas, mudah putus asa dan sebagainya. Dalam ajaran Islam sikap dan tingkah laku seperti itu merupakan perbuatan tercela dan dimurkai Allah SWT. Untuk menyembuhkan penyakit-penyakit itulah Rasulullah SAW, diutus ke dunia ini. Semua perkataan, perbuatan, sikap dan gerak-gerik Rasulullah merupakan keteladanan dan contoh yang baik dan benar bagi manusia (Dzaky, 2001: 244).

Dan jelas bahwa psikoterapi Islam: erat kaitannya dengan perawatan ruhani Islam ilmu ini membantu sisi terapi spiritualitas atau psikhis manusia dengan paradigma psiko-teo-antroposentris yaitu jenis psikoterapi yang berbasis pada agama (psikoterapi religius) yang bersandar pada keMahamutlakkan Tuhan dan upaya maksimal manusia melalui tujuh metode psikoterapi yang telah dikembangkan yaitu terapi dengan: 1) al-Qur'an), 2) Do’a, 3) dzikir, 4) shalat, 5) puasa, 6) mandi, wudhu (hidroterapi), 7) hikmah, 8) tashawuf dan tharikat (Arifin, 2008: 33)

Kemudian teori yang berkenaan tentang penyakit maksiat, dalam Kitab Mu’jamul Arobi disebutkan arti kata sعصية “ma'syhiyah” merupakan bentuk "mashdar" dari kata kerja عصىر, hal itu merupakan bentuk perkataan yang menunjukan kata benda. Kata "maية "syhiyah" sendiri mempunyai persamaan arti dengan kata مخالفة "mukholafah" yaitu Menentang, menyelisihi ataupun mendurhakai. Dan kata معصبية "ma'syhiyah" merupakan akronim atau lawan dari kata طاعة "tho'at” yang berarti mentaati, mematuhi atau tunduk. 
Terapi Penyakit Maksiat Menurut Ibnu Al-Qayyim Al-Jauziyyah

Sedangkan secara istilah arti kata معصية “ma”syhiyah” itu sendiri ialah suatu bentuk kesalahan moral yang dimotivasi oleh kehendak yang tidak baik dan hal ini disebut secara khusus untuk menyatakan pelanggaran akan perintah ilahiyah.

Fathi al-Duraini, sorang ahli Ushul Figh, memberikan pengertian arti kata maksiat sebagai segala perbuatan yang sifatnya meninggalkan yang wajib dan mengerjakan apa yang diharamkan. Hal tersebut menyangkut apakah perbuatan itu berkaitan dengan hak-hak Allah ataupun yang berkaitan dengan hak-hak seseorang (Harjadi, 2002:133).

\section{HASIL DAN PEMBAHASAN}

Penelitian ini membahas mengenai isi dari kitab Al-Dã'u Wa Al-Dawãu (Macam-Macam Penyakit dan Obatnya), Kitab ini mempunyai judul asli " $A l$ Jawabu Al-Kafi liman Sa'ala An Ad-Dawaa Asy-Syafi” hal ini merujuk kepada dasar pembuatan kitab ini berasal dari fatwa-fatwa Imam Ibnu Al-Qayyim AlJauziyyah akan permasalahan-permasalahan klien atau Jama'ah. Mengingat penulisan buku ini terjadi pada masa akhir peperangan dan awal penetapan hukuman bagi tentara perang salib yang tertangkap, banyak sekali persoalan yang dibahas dalam kitab ini berupa Tazkiyatu $A n-N a f s$ atau pensucian jiwa. Melalui fatwa beliau ingin membantu para klien mengembalikan konsep diri dan meningkatkan kualitas umat saat itu.

Kitab Al-Dã'u Wa Al-Dawã'u memiliki beberapa cetakan, dan yang terkenal pada kalangan mahasiswa Al-Azhar dengan nama $A l-D \tilde{a}$ 'u $W a A l-$ Daw ãu. Kitab ini sudah banyak dicetak dan diterjemahkan salah satunya diterbitkan oleh Dar Ibnu Al-Jauzi di Mesir. Kitab ini merupakan cetakan kedua yang terbit pada tahun 2012. Buku ini sebagaimana judulnya, berisi tentang terapi terhadap berbagai macam penyakit kemaksiatan yang telah menggerogoti hati manusia, termasuk didalamnya kebodohan, bahayanya didunia dan akhirat kemudian terapi atau obat mujarab berdasarkan Al-Quran dan As-Sunnah. Disamping itu buku ini syarat dengan nasihat, petuah, peringatan, pelajaran, hikmah dan ilmu pengetahuan yang sangat dibutuhkan oleh siapa saja yang mengharapkan keselamatan, kesehatan, keberhasilan, dan kebahagiaan dunia dan akhirat.

Kitab Al-Dã'u Wa Al-Dawã'u tidak ditulis secara sistematis dan focus pada satu tema tertentu saja, hal ini dikarenakan berlatar belakang fatwa. Sebagai permulaan, diawal bahasan penulis memaparkan pentingnya Do'a dan kaitanya dengan takdir, lalu dilanjutkan dengan macam-macam penyakit maksiat dan dosa serta dampak negatifnya. Pada bahasan berikutnya, penulis membahas tentang hukuman dan jenis jenis hukuman Allah SWT, lalu disusul dengan pembahasan syirik dan macam-macamnya. Kemudian pembahasan mengenai dosa besar, seperti membunuh, dosa zina, dzalim, dan lain-lain beserta dampak negative perbuatan tersebut terhadap pelakunya. Bahkan 
S. M. Putra., I. Z. Arifin., S. Chodijah.

dibahas juga tentang masalah kasmaran, penyelewengan seksual dan lain-lain.

\section{Biografi Syaikh Ibnu Al-Qayyim Al-Jauziyyah}

Nama beliau adalah Abu Abdillah Syamsuddin Muhammad ibnu Abi Bakr Ibnu Ayyub Ibnu Haris Ibnu Makki Zainuddin az-Zur'i ad-Damasyqi, yang lebih terkenal dengan julukan Ibnu al-Qayyim al-Jauziyyah. Hal ini dikarenakan ayahnya yang berprofesi sebagai seorang kepala sekolah pada madrasah yang beri nama al-Jauziyah di daerah Damaskus (Qayyim, 2001: 14). Beliau dilahirkan pada tanggal 7 Shafar $691 \mathrm{H}$, tepatnya setahun setelah orangorang Kristen terkalahkan dan ditetapkan hukuman atas mereka.

Allah SWT, telah memberikan kemampuan yang berilian kepada beliau, daya hafal yang sangat kuat, jiwa yang jernih, batin yang bersih dan pengetahuan yang luas (Qayyim, 2001: 14) hal itu terindikasi dari ketekunan beliau dalam mengkaji berbagai ilmu pengetahuan. Beliau sangat tekun dalam belajar, mengajarkan dan membuat karya tulis, dan memang terbukti Ibnu al-Qayyim al-Jauziah rabimabullahu ta'ala merupakan sosok yang A'lim pada zamanya.

Ayahnya adalah Abi Bakar ibn Ayyub az-Zur'i. Beliau merupakan kepala sekolah madrasah al-Jauziyyah. Beliau terkenal karena kesalihannya, tidak suka berpura-pura dan sangat ahli dan meguasai disiplin ilmu Fara’idl (Ilmu Pembagian Waris). Beliau meninggal secara mendadak di dalam madrasahnya dan jenazah beliau rahimahullah ta'ala dimakamkan di Baabus Shafir di Damaskus (Katsir, XIV: 95).

Dari Silsilah keturunan Syaikh Ibnu al-Qayyim al-Jauziah memiliki dua orang putra yaitu: Pertama, Syarafuddin Abdullah yang lahir pada tahun $723 \mathrm{H}$. Beliau termasuk anak yang sangat cerdas dan hafidz al-Quran (Penghafal alQuran). beliau lah yang ditunjuk sebagai pengganti ayahnya setelah ayahnya meninggal untuk mengajar di Shadriyyah, beliau mendalami hukum dan Syari'at demi memerangi berbagai Bid'ah. Beliau meninggal pada tahun $756 \mathrm{H}$, tepatnya lima tahun setelah wafat mendiang ayahnya (Katsir, XIV/202).

Kedua, Burhanuddin Ibrahim Ibnu Syamsuddin. Beliau lahir pada tahun 716 H. Beliau menimba ilmu dari ayahnya sendiri dan juga dari Madrasah Shadriyyah, hingga akhirnya beliau dipercaya untuk menjadi mufti dan beliau terkenal sebagai ulama ahli bahasa yang menguasai ilmu nahwu (Ilmu tata bahasa Arab). Beliau termasuk ulama yang mentasyrih kitab Alfiyah Ibnu Malik dan kitab syarahnya terkenal dengan nama Irsyãdus Sãlik Illa Alfiyah Ibnu Malik. Beliau meninggal pada tahun $767 \mathrm{H}$ (Hajar, 1/60).

Ibnu al-Qayyim al-Jauziyah rahimahullahu ta'ala hidup disuatu masa yang telah diawali berbagai macam kejadian besar. Pengaruh berbagai peristiwa besar itu masih sangat terasa dalam kebudayaan dan masyarakat dimasa beliau. Bahkan efeknya masih terus terasa pasca masa beliau dalam kurun waktu yang cukup lama. Dan efek tersebut sampai mempengaruhi kondisi sosial 
Terapi Penyakit Maksiat Menurut Ibnu Al-Qayyim Al-Jauziyyah kemasyarakatan dan situasi keagamaan serta intelektual, sehingga dapat diketahui dengan jelas bagaimana pengaruh runtuhmya Baghdad, dengan diumumkannya ke khalifahan Suriah di Mesir dan para penguasa yang saling bertikai. Dan masih banyak lagi fitnah yang membuat efek negetive bagi kehidupan masyarakat pada waktu itu.

Terjadinya persaingan agama dan peradaban antara kaum muslim dan kaum kristiani disatu pihak dan munculnya fanatisme agama dipihak lain menyebabkan mudahnya tercuat konflik keagamaan dikalangan kaum muslimin. Masing-masing individu merasa benar dan terlalu percaya diri. Oleh karena itu para ulama kaum muslimin merasa bahwa amanat yang diemban harus segera mereka laksanakan dihadapan umat. Walau cara mengekspresikan amanat tersebut lebih bersifat menghakimi pihak lain menurut perspektifnya sendiri. Berangkat dari sikap sebagai pihak yang berhak memberi hukuman itulah tidak jarang para ulama memberikan putusan-putusan yang terlampau tegas, seperti hukum penjara, pembuangan ditempat terkucil dan bentuk penyiksaan lainnya. Karena pada waktu itu ulama memiliki peran kunci dalam mengatur barisan mujahidin dari kaum muslimin.

Tujuan mereka sebenarnya untuk memberikan dukungan kepada orang-orang yang ikhlas dalam beramal di dalam menolak bahaya ekspansi dari pihak luar dan mempertahankan tanah air mereka. di antara kiat yang dilakukan oleh para ulama untuk megatasi berbagai masalah dengan memberikan nasehat kepada amir, khalifah dan para sultan. Dari sebagian hasil penafsiran pendapat mereka itulah akhirnya Ibnu Qayyim bersama gurunya, Ibnu Taimiyyah rahimahumallahu ta'ãla terpaksa harus dijebloskan di balik jeruji-jeruji besi. Mungkin dari sinilah munculnya beberapa permasalahan tentang kebebasan mulia dari segi politis sampai intelektual yang dapat kita jumpai dalam pembahasan ilmiyah Ibnu al-Qayyim al Jauziyyah dan syaikhnya Ibnu Taimiyyah.

Dari bidang keilmuan, ada persaingan peradaban dari kaum kristiani dan bangsa mongol yang selalu saja ingin menyerang kebudayaan Arab Islam. usaha yang mereka kerahkan cukup berbahaya dan mengancam eksistensi kesatuan budaya umat Islam. namun dari pergolakan itulah malah melahirkan semangat baru dalam dunia ilmu pengetahuan di kalangan kaum muslim. Telah banyak karya ilmiyah yang bernuansa ensiklopedik dari hasil jerih payah generasi baru. Hal ini terwakili dalam pusat-pusat khazanah keilmuan baik di Mesir maupun di daerah Syam. Seperti misalnya yang terdapat di masjid Jami' al Azhar dan Jami' Ibnu Thulun di Mesir. Begitu juga dengan Madrasah ad-Dzahiriyyah, Madrasah al-'Adiliyyah al-Kubra, Madrasah alJauziyyah dan Madrasah as-Shadriyyah di daerah Syam.

Akhir masa keemasan pada zaman itu ialah ketika beliau menghembuskan nafasnya yang terakhir pada malam kamis pada tanggal 13 
S. M. Putra., I. Z. Arifin., S. Chodijah.

Rajab 751 H(Katsir, IV: 202). Sejak saat itu bintang Ibnu Qayyim padam setelah sebelumnya menyala sangat terang. Kehidupan beliau telah dipenuhi dengan kegiatan ilmiah yang sudah menembus jauh melebihi batasnya. Bahkan tidak ada seorang pun baik yang hidup sebelumnya ataupun yang hidup sesudah beliau yang bisa melebihi keseriusan beliau dalam mengarang. Banyak sekali yang mengiring jenazah Ibnu al-Qayyim al-Jauziyyah rabimabullahu ta'äla sampai ketempat peristirahatan terakhir.

Jenazah Ibnu Qayyim dishalati setelah shalat dzuhur sehari berikutnya di masjid Jami al-Jarah. Masjid yang terletak dengan komplek pemakaman alBãbus Shagîr di Damaskus. Akhirnya jenazah beliau dikebumikan dikomplek pemakaman al-Bãbus Shagîr di Damaskus di samping makam ibundanya (Zaid, 2001: 198-199). Semoga Allah memasukkan beliau ke dalam surga dan memberikan manfaat ilmu-ilmu beliau kepada kita semua yang ditinggalkan. Al-Qadli Burhanuddin az-Zur'I berkata: "Tidak ada dibawah kolong langit ini seorang yang sangat luas ilmu pengetahuannya dengan sejumlah daftar karya ilmiyah dibanding dengan beliau"(Rojab, 2: 593).

\section{Konsep Penyakit Maksiat Menurut Ibnu Al-Qayyim al-Jauziyah Ra.}

Menurut Ibnul Qayyim al-Jauziah dalam Kitabnya al-Dãu wa al-Dawã'u menjelaskan bahwa yang dimaksud dengan penyakit maksiat itu sendiri terbagi menjadi tiga definisi; Pertama, dalam kitab beliau halaman 48 beliau menjelaskan sejatinya penyakit maksiat ialah suatu penyakit yang jika berkesinambungan akan dapat menghancurkan kehidupan dunia dan akhirat seorang hamba. Menurut beliau penyakit maksiat menimbulkan Mudharat (Kerugian). tidak mungkin tidak, mudharatnya bagi Hati sebagaimana Mudharat yang ditimbulkan racun bagi tubuh, hal itu memiliki tingkatan yang beragam. Dan hal ini sudah jelas, adakah kehinaan dan penyakit didunia dan diakhirat yang tidak disebabkan dosa dan penyakit maksiat?

Sebagai contoh bahwa bapak kita Nabi Adam AS dan Siti Hawa dikeluarkan dari Surga Allah SWT karena Penyakit Maksiat, Iblis dikeluarkan dari kerajaan langit kemudian dihinakan dan dilaknat karena penyakit maksiat, bukankah penyakit maksiat juga yang membuat bumi tenggelam hingga menutupi puncak-puncak gunung, karena penyakit maksiat, Allah SWT kirimkan Angin kepada kaum A'd hingga membuat mayat-mayat mereka bertebaran bagaikan pelepah kurma yang lapuk. Karena penyakit maksiat, Allah SWT angkat desa kamu Luth hingga para malaikat dapat mendengar lolongan anjing-anjing mereka kemudia Allah SWT balikkan desa beserta penduduknya, atas menjadi bawah hingga binasa seluruh penduduknya. Karena penyakit maksiat, Allah SWT benamkan Qarun beserta harta, tempat tinggal dan keluarganya. Dan karena penyakita maksiat, Allah SWT kirimkan Awan Adzab kepada kamu Syu'aib hingga saat sampai diatas kepala mereka, Allah SWT 
turunkan hujan api yang menyala-nyala.

Hal ini yang membuat arti dari Penyakit Maksiat menurut Syaikh Ibnu al-Qayyim al-Jauzyi memiliki kesamaan makna dengan sabda Nabi SAW yang Artinya;

"Manusia tidak akan binasa dan mendapatkan kerugian hingga diri mereka banyak berbuat dosa (terjangkit penyakit maksiat) (Ahmad, IV/260).

Kedua, Pada halaman 62 beliau menjelaskan bahwa pengertian dari penyakit maksiat menurut Ibnu al-Qayyim al-Jauziyah ialah setiap perbuatan yang buruk, keluar dari norma serta dapat membahayakan hati dan badan baik itu didunia maupun diakhirat. Maka bagi seorang hamba yang terserang penyakit maksiat ia senantiasa keluar dari jalan Allah SWT, menjauhi dan sibuk dengan perkara-perkara dosa. Maka sungguh akan sirna kehidupan hakikinya (Ibadah kepada Allah SWT ) dan pelakunya akan merasakan akibat dari penyakit maksiat yang ia derita pada hari dimana ia menyesal dan berkata:

"... Alangkah baiknya sekiranya dabulu (ketika aku didunia) aku mengerjakan (kebajikan) untuk bidupku ini." (Depag, 2015: 594).

Ketiga, pada halaman 65 pengertian penyakit maksiat menurut Ibnu alQayyim al-Jauziyah ialah suatu perbuatan durhaka yang menanamkan perbuatan kedurhakaan dan keburukan yang lainya. Sampai-sampai pengidap penyakit tersebut akan sulit untuk meninggalkan dan keluar dari penyakit tersebut.

Sebagian ulama salaf mengatakan: "Hukuman dari keburukan ialah munculnya keburukan setelahnya, sedangkan ganjaran dari kebaikan adalah munculnya kebaikan sesudahnya. Maka bagi seorang hamba jika melakukan kebaikan, kebaikan yang lain akan berkata padanya: "Kerjakan aku juga", dan apa bila hamba tersebut melakukanya maka kebaikan yang lain juga akan meminta untuk dikerjakan dengan mengatakan hal serupa dan demikianlah seterusnya. Maka kelak akan berlipat gandalah keuntungan dan bertambahlah kebaikan. Demikian pula pada pelaku dosa dan pengidap penyakit maksiat. Hal ini akan terus berlaku hingga penyakit maksiat ataupun ketaatan menjadi suatu sifat dan kebiasaan yang melekat pada diri seseorang hamba.

Maka sungguh jelas bahwa penyakit maksiat memiliki berbagai dampak yang buruk, tercela, serta membahayakan hati dan badan, didunia maupun di akhirat nanti, yang mana jumlahnya tidak diketahui secara pastinya kecuali oleh Allah SWT semata. Maka untuk memperuncing dampak dari penyakit maksiat penulis mencoba mengelompokan diantara dampak kemaksiatan yang dimaksud dapat dikategorisasikan menurut tujuan dari ditetapkannya suatu hukum Syariat (Al-Maqashidu Asy-Syariah). Sehingga jelas bagi siapa yang mencederai tujuan di tetapkanya hukum dalam islam dia termasuk kedalam orang yang terjangkit penyakit maksiat. Abu Ishaq as-Syatibi merumuskan $\mathrm{Al}$ Maqashid Asy-Syariah kedalam lima tujuan, yakni: Pertama, Hifdzu ad-Din (untuk 
menjaga Agama). Kedua, Hifdzu an-Nafs (untuk menjaga Jiwa). Ketiga, Hifdzu alAql (untuk menjaga Akal). Keempat, Hifdzu an-Nasab (untuk menjaga Keturunan) dan Kelima, Hifdzu al-Maal (untuk menjaga Harta dan Kehormatan) (Syatibi, 2006: 10).

\section{Terapi Terhadap Penyakit Maksiat}

Sebelum seorang terapis mengetahui suatu permasalahan dari klien maka perlu melalui beberapa tahapan-tahapan terapi, hal ini bisa didapat dari Syai'r Imam As-Syafi'I pada kitab Al-Dã'u Wa Al-Dawã'u halaman 63 yang berbunyi:

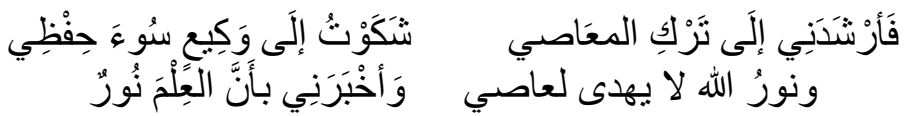

"aku mengadu kepada waqi' tentang buruknya bafalanku - maka beliau menasihatiku agar aku tinggalkan kemaksiatan. Beliau pun mengabariku bahwa ilmu merupakan cahaya - dan cahaya Allab tidak akan diberikan kepada pelaku maksiat." kutip

Hal pertama yaitu adanya wawancara. Hal ini seperti yang terjadi ketika Imam as-Syaafi'i dan Imam Malik dan juga ketika Imam Wakii' ibn al-Jarraah bertemu muridnya Imam as-Syafii' mereka mengadakan wawancara. Kemudaian hal kedua setelah diadakan wawancara, Imam Wakii' menanyakan penyebab kenapa hafalanya menjadi lemah. Maka Imam as-Syafi'i menjawab bahwa beliau tidak sengaja melewati sebuah pasar dan melihat betis seorang wanita yang tidak sengaja tersingkap. Maka Imam Wakii’ memberikan petunjuk yang dapat diterapkan yaitu untuk meninggalkan perbuatan Maksiat. Dan diakhir proses terapi dengan memberikan perumpamaan bahwa ilmu merupakan cahaya dan keutamaan (Fadhilab) sedangkan cahaya dan Keutamaan Allah SWT tidak akan diberikan kepada pelaku maksiat.

Metode dan tekhnik yang diterapkan oleh Syaikh Ibnu al-Qayyim alJauziyyah rabimabullabu 'anbu dapat dikategorisasikan menurut dampak dari penyakit maksiat itu sendiri. Pertama, Dampak penyakit maksiat terhadap Agama pada halaman 67, maka terapi yang diberikan ialah dengan metode "Irsyãd" atau bimbingan konseling, yaitu dengan memberikan penjelasan objektif mengenai penyakitnya tersebut. maka setelah klien diberikan Bimbinga dan konseling tetapi masih belum mampu menyadarkannya maka perlu adanya "at-Tabyîn" atau penjelasan yang lebih menyeluruh, sehingga klien memahami lebih dalam lagi akibat dari perbuatanya, jika masih belum mampu merubahnya dan masih melakukan perbuatan tersebut maka baginya "at-Tanbîh" atau peringatan keras terhadap perilaku tersebut, hal ini bisa berupa ancaman siksaan dan ancaman untuk ditimpakan hukuman, dan apa bila masih melakukannya maka baginya hukuman as-Syarî'ah atas perbuatannya. Kedua, Dampak penyakit 
Terapi Penyakit Maksiat Menurut Ibnu Al-Qayyim Al-Jauziyyah maksiat terhadap Jiwa pada halaman 119, maka proses terapi yang diberikan ialah dengan "at-Tabyin" yaitu memberikan penjelasan akibat dari perbuatannya dan juga sekaligus memberikan "al-Tabdîd" atau ancaman. Hal ini dilakukan diterapkan melalui tekhnik "Amr bi at-Taqwa wa Nabyu an al-Ma'shiyab" menyuruh kepada ketakwaan dan melarang dari perbuatan maksiat. Kemudian terapi selanjutnya ialah dengan melakukan "al-Birru” atau perkara yang baik dan juga "al-Tha'atu” atau perkara yang membawa kepada ketaatan. Maka jika masih saja melakukannya baginya peringatan tentang hukuman dan juga tentang hari pembalasan. Menurut beliau jika ada yang merasa berat dengan perkara diatas dapat juga diterapkan terapi berikut seperti yang terkandung dalam al-Quran Surat At-Taubah ayat 112:

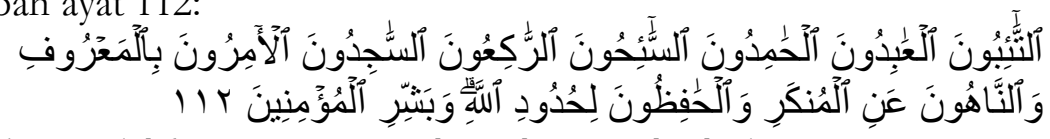

"Mereka itu adalah orang-orang yang bertaubat, yang beribadat, yang memuji, yang melawat, yang ruku', yang sujud, yang menyurub berbuat ma'ruf dan mencegah berbuat munkar dan yang memelihara bukum-bukum Allah. Dan gembirakanlab orang-orang mukmin itu" (Depag, 2015: 205)

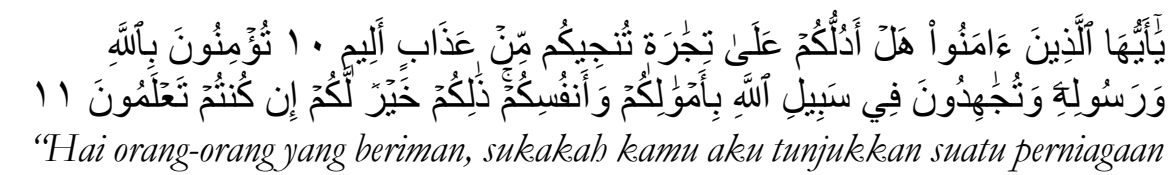
yang dapat menyelamatkanmu dari azab yang pedih - (yaitu) kamu beriman kepada Allah dan Rasul-Nya dan berjibad di jalan Allab dengan harta dan jiwamu. Itulah yang lebih baike bagimu, jika kamu mengetahui" (Depag, 2015: 552).

Hal ini maksudnya ialah ketika seorang terapi melihat seorang pengidap maksiat lupa dengan perdagangan yang menguntungkan, dan terlalu sibuk dengan perdagangan yang merugikan jiwanya maka bagi terapis untuk mengingatkan tentang makna dari dua ayat diatas. yaitu mengenai konsep taubat, ibadah, memuji Allah dengan mengucap "Alhamdulillah", ruku'. Sujud, dan amar ma'ruf nahi munkar.

Ketiga, Dampak penyakit maksiat terhadap akal halaman 69, maka proses terapinya ialah menggunakan metode mauidzoh yaitu dengan mengingatkan kepada al-Qur'an, keimanan, kematian, neraka dan juga kepada hal yang dapat menghilangkan kebaikan pahala didunia dan akhirat sedikit demi sedikit. Selain menggunakan Mauidzah juga pengidap penyakit maksiat diberikan perumpamaan-perumpamaan dan juga dianjurkan bagi pengidap penyakit yang telah merusak akalnya maka baginya untuk berteman bersama orang-orang yang Shalih dan Alim, sehingga dia akan lebih mengenal tentang kebenaran dan juga kebathilan, dan juga dampak-dampak buruknya pula akan dijelaskan dan akan ada interaksi saling menasehati diantara mereka. Sebagaimana Allah SW'T sifati orang yang beriman dalam al-Qura'n surat Al-

Irsyad : Jurnal Bimbingan, Penyuluhan, Konseling, dan Psikoterapi Islam 07(4) (2019) 423-438 
A'shr ayat 1-3:

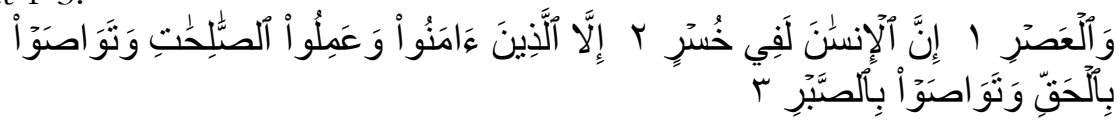

"Demi masa - Sesunggubnya manusia itu benar-benar dalam kerugian - kecuali orang-orang yang beriman dan mengerjakan amal saleb dan nasebat menasehati supaya mentaati kebenaran dan nasehat menasehati supaya menetapi kesabaran" (Depag, 2015: 601).

Keempat, Dampak penyakit maksiat kepada keturunan halaman 69, menurut Ibnu al-Qayyim al-Jauziyyah rahimahullahu 'anhu hal ini dapat dicegah dan diobati dengan prilaku ketaatan dan juga menggunakan metode Do'a, salah satu do'a yang beliau ajarkan dari para ulama terdahulu ialah:



"Ya Allah, muliakanlah aku dengan menaati-Mu dan jangan hinakan aku dengan mendurhakai-Mu”.

Kelima, Dampak penyakit maksiat terhadap harta dan kehormatan pada halaman 98, proses terapinya menyangkut masalah ketakwaan, maka terapi menurut Syaik Ibnu al-Qayyim al-Juaziyyah ialah dengan dakwah untuk kembali kepada ketakwaan dan meninggalkan kemaksiatan, kedzaliman dan kerusakan. Kemudian dijelaskan pula padanya tentang akibat dan "al-ta'lîl'" atau alasan dari ditentukannya hukum tersebut. dan terapi yang dapat diterapkan juga terdapat dalam hadist riwayat at-Tirmidzi, Rasulullah SAW bersabda:

الدنيا ملعونة ملعون من فيها إلا عالما أو متعلما أو ذكر الله وما و لاه

"Dunia terlaknat, dan terlaknat apa yang ada didalamnya, kecuali driker kepada Allah SWT, amal-amal kebaikean yang dicintai Allab SWT, orang yang berilmu dan orang yang menuntut ilmu” (Tirmidzi, 14: 2322).

Maka setelah prosesi terapi yang diberikan terdapat perubahan yang ditimbulkan dari terapi yang digunakan oleh Syaikh Ibnu al-Qayyim al-Jauziyah rahimahullahu 'anhu dan itu berbeda-beda, hal ini dilihat dari kualitas keimanan dan ketakwaan tiap individu dan juga dari tingkatan amal yang dilakukan seorang pengidap penyakit maksiat dalam proses terapinya. Amalan yang dapat menghilangkan penyakit ini terdapat tiga tingkatan: Pertama, Hanya mampu dosa kecil disebabkan kelemahannya, yaitu kurangnya ikhlas, serta kurang terpenuhi hak-haknya. Sebagaimana suatu obat yang kurang manjur, lemah terhadap penyakit, karena disebabkan oleh kurangnya kuantitas maupun kualitasnya.

Kedua, amalan hanya dapat menyembuhkan penyakit yang kecil saja tapi belum mampu mengobati penyakit yang lebih besar. Ketiga, amalan yang mampu menghapus dosa kecil dan sekaligus kekuatanya masih bisa untuk menghapus dosa dan penyakit yang besar. Maka, bisa jadi penyakit maksiat yang ada pada tiap individu tidak hanya merusak satu aspek, bisa jadi dua, tiga bahkan bisa jadi 
Terapi Penyakit Maksiat Menurut Ibnu Al-Qayyim Al-Jauziyyah penyakit maksiat telah merusak kelima aspek sekaligus. Hal ini yang membuat seorang terapis sebaiknya tidak hanya terpaku oleh satu metode saja akan tetapi dituntut untuk dapat menggabungkan beberapa metode sekaligus. Sehingga keberhasilan terapi akan lebih mudah dicapai.

\section{PENUTUP}

Dari sekian banyak pembahasan yang telah dipaparkan, dapat ditarik kesimpulan sebagai berikut: pertama, 1. Biografi Ibnu Al-Qayyim Al-Jauziyyah yaitu Abu Abdillah Syamsuddin Muhammad ibn Abi Bakr Ibn Ayyub Ibn Haris Ibn Makki Zainuddin az-Zur'i ad-Damasyqi, yang lebih terkenal dengan julukan Ibnu al-Qayyim al-Jauziyyah. dilahirkan pada tanggal 7 Shafar 691 H. Syaikh Ibnu al-Qayyim al-Jauziah memiliki dua orang putra yaitu Syarafuddin Abdullah yang lahir pada tahun $723 \mathrm{H}$ dan Burhanuddin Ibrahim Ibn Syamsuddin. Beliau lahir pada tahun 716 H. Syaikh Ibnu Al-Qayyim Al-Jauziyyah memiliki guru bernama Syaikh Ibnu At-Taimiyyah bersama gurunya beliau banyak mengarang buku dalam berbagai bidang ilmu seperti, Ilmu Fiqh, Tazkiyatun Nafs, Ilmu Bahasa seperti Nahwu dan Lain Sebagainya. beliau menghembuskan nafasnya yang terakhir pada malam kamis pada tanggal 13 Rajab $751 \mathrm{H}$ dan Jenazah Ibnu Al-Qayyim dishalati setelah shalat dzuhur sehari berikutnya di masjid Jami al-Jarah. Masjid yang terletak dengan komplek pemakaman al-Bãbus Shagîr di Damaskus. Akhirnya jenazah beliau dikebumikan dikomplek pemakaman al Bãbus Shagîr di Damaskus.

Kedua, Konsep maksiat menurut Ibnu al-Qayyim al-jauziyyah RA, beliau membagi menjadi tiga pengertian: Pertama, maksiat merupakan suatu penyakit dan racun bilamana berkesinambungan maka akan menghancurkan kehidupan dunia dan akhirat seorang hamba. Kedua, setiap perbuatan yang buruk, keluar dari norma serta dapat membahayakan hati dan badan baik itu didunia maupun diakhirat. Ketiga, suatu perbuatan durhaka dan buruk yang menanamkan perbuatan kedurhakaan dan keburukan yang lainya. Sampai-sampai pengidap penyakit tersebut akan sulit untuk meninggalkan dan keluar dari penyakit tersebut.

Ketiga, Terapi penyakit maksiat menurut Ibnu al-Qayyim al-Jauziyah, dilihat dari dampak yang ditimbulkan oleh penyakit maksiat ada lima yaitu: Pertama, Penyakit maksiat merusak Agama maka terapi yang digunakan adalah irsyãd (Bimbingan dan konseling), tabyîn (Penjelasan lebih menyeluruh), tanbîh (Peringatan dan ancaman) dan hukum syariah atas Jarimah yang diperbuat. Kedua, Penyakit maksiat merusak Jiwa maka terapi yang digunakan adalah attabyîn (Penjelasan) dan at-tabdîd (Ancaman), Amr bi at-Taqwa wa Nabyu an alMa'syiyah (Menganjurkan kepada ketakwaan dan melarang dari perbuatan maksiat), al-birru (Kebaikan) dan at-tha'atu (Ketaatan). Ketiga, Penyakit maksiat merusak akal maka terapi yang digunakan adalah dengan Mauidzah tentang al- 
S. M. Putra., I. Z. Arifin., S. Chodijah.

Quran, al-Iman (Keimanan), al-Maut (Kematian), an-Nar (Neraka) dan juga perkara yang membuat kerusakan dunia dan akhirat, memberikan perumpamaan-perumpamaan, menganjurkannya untuk berteman dengan orang shalih dan alim sehingga akan lebih memahami kebenaran dan kebaikan darinya. Keempat, Penyakit maksiat merusak keturunan maka terapi yang digunakan adalah prilaku ketaatan dan metode Do'a. Kelima, Penyakit maksiat merusak harta dan kehormatan maka terapi yang digunakan adalah dakwah kepada ketakwaan dan meninggalkan kemaksiatan, kedzaliman dan kerusakan, dijelaskan juga al-A'qibah (Akibat) dan al-Ta'lal (alasan disyariatkan hukum), dan terapi Dzikir.

\section{DAFTAR PUSTAKA}

Al-Munawwar. (2015). Al-Quran dan Terjemah Depag. Jakarta: Cipta Bagus Segara. Al-Syathibi, A. I (2006). Al Munvafaqot fil Ushul Syaria't. Cairo: Dar Al-Hadist. Anshori, F. (2000). Aplikasi Psikologi Islam. Skripsi, Jurusan Psikologi, UIN Sunan Kalijaga, Yogyakarta.

Arifin, I. Z. (2008). Bimbingan dan Konseling Islam Berbasis Ilmu Dakwah dalam Ilmu Dakwah: Academic Journal for Homiletic Studies, 4(11), .27-42.

Harjadi, B. (2002). Ensiklopedia Islam. Jakarta: Ihtiar Baru Van Hove

Chaplin, J. P. (1995). Kamus Psikologi (terjemahan Kartono, K). Jakarta: Rajawali. Darajat, Z. (1976). Perawatan Jiwa untuk. Anak. Jakarta: Bulan Bintang.

Echol, J. M dan Shadily, H. (2005). Kamus Inggris - Indonesia. Jakarta: Gramedia Pustaka Utama.

Gunarsa, S. D. (1992). Konseling dan psikoterapi. Jakarta: Gunung Mulia.

Hawari, D. (1997). Al-Qur'an Ilmu Kedokteran Jiwa dan Kesebatan Jiwa. Yogyakarta: Victor Jaya Abadi.

Hawari, D. (2002). Dimensi Religi dalam Praktek Psikiatri dan Psikologi. Jakarta: FKUI.

Jauziyyah, I.Q. (1992). Al-Daa' wa Al-Dawaa. Beirut: Dar Al-Fikr.

Jauziyyah, I. Q. (2005). Manajemen Qalbu Melumpubkan Senjata Syaithan ter Ainul Haris Umar Arifin. Jakarta: Darul Falah.

Jauziyyah, I. Q. (2005). Terapi Penyakit Hati. Jakarta: Qisthi Press.

Katsir, I. (2013). Al-Bidayah Wa An-Nihayah. Jakarta: Pustaka As-Sunnah.

M. Sholikhin, 2003. Terapi Sufistik Penyembuban Kejiwaan Perspektif Tasawuf. Bandung: CV. Pustaka Setia.

Najati, M,U. (2005). Psikologi dalam Al-Qur'an ter. M. Zaka Alfarisi. Bandung: Pustaka Setia. 